\title{
刺激応答性高分子材料：構造の制御された 温度応答性ポリマーの展開
}

\section{Stimuli-Responsive Polymers: Recent Advances in Thermosensitive Polymers with Well-Controlled Structures}

\section{青島 貞人 \\ 大阪大学大学院理学研究科高分子科学 専攻 \\ T 560-0043 \\ 大阪府豊中市待兼山町 1-1 \\ Sadahito AOSHIMA \\ Department of Macromolecular \\ Science, Graduate School of Science, Osaka University}

1-1, Machikaneyama, Toyonaka, Osaka 560-0043, Japan

\section{金岡 鐘局}

大阪大学大学院理学研究科高分子科学 専攻

干 560-0043

大阪府豊中市待兼山町 1-1

Shokyoku KANAOKA

Department of Macromolecular

Science, Graduate School of Science, Osaka University

1-1, Machikaneyama, Toyonaka, Osaka 560-0043, Japan
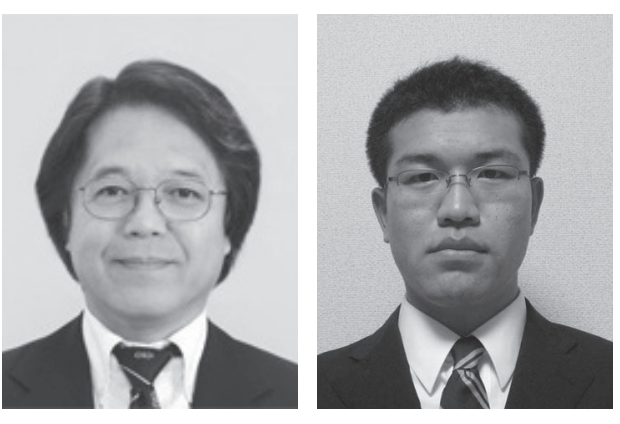

金澤 有紘

大阪大学大学院理学研究科高分子科学 専攻

T 560-0043

大阪府豊中市待兼山町 1-1

Arihiro KANAZAWA

Department of Macromolecular

Science, Graduate School of Science,

Osaka University

1-1, Machikaneyama, Toyonaka, Osaka 560-0043, Japan

論文要旨：近年, 様々な分野への応用を見据えた, 刺激応答性高分子材料の創製が注目されている。本報 では，その中でも検討が進んでいる，水中で高感度な応答を示す温度応答性ポリマーを中心に概説する。特 に，最近の高分子合成技術の進歩は著しく，例えばリビングラジカル重合により多数のモノマーから構造や 分子量の制御されたリビングポリマーが合成されるようになり，その結果，種々の刺激応答性ブロックポリ マーなどの新しい材料が創製されている。ポリ（N-イソプロピルアクリルアミド）をはじめとするポリア ミド系とポリ（エチレンオキシド）を側鎖に有するポリエーテル系がその代表例である。本文中では，それ らのリビング重合による精密合成法からはじまり，温度応答性の特徵や自己組織化にも触れる。また，その 後次々と合成されているアミド系, エーテル系のポリマーの例を示し, ポリマー構造と刺激応答挙動の関係 を明らかにする。後半部分では, 温度応答性ポリマーの典型的な例として，われわれが検討している刺激応 答性を有する星型ポリマーや選択的分解性を合わせ持つポリマーの合成, ドラッグデリバリーに利用可能な 温度応答性リポソームの例を示す。 
Abstract: This review highlights the newly developed thermosensitive polymers exhibiting a sharp thermosensitive phase transition in water, as the representative stimuli-responsive polymers. Especially, recent precision synthesis via living polymerization has created new possibilities to a variety of stimuli-responsive polymers. Poly( $N$-isopropylacrylamide) [poly(NIPAM)] and a wide range of other thermoresponsive polyamides with well-defined structures have been synthesized by mainly living radical polymerization. Furthermore, various block copolymers were extensively synthesized and their characteristic thermosensitive behaviors and their applications to the biomedical fields were demonstrated. On the other hand, polymers with oxyethylene groups exhibited also a sharp thermosensitive phase transition in water. For example, a variety of thermosensitive poly(vinyl ether)s with controlled sequences and/or shapes such as various block copolymers and star-shaped polymers were designed and synthesized by living cationic polymerization. In addition to the selective synthesis, the thermosensitive behavior of polymers with oxyethylene groups is briefly reviewed. The recent progress in the investigations on thermosensitive poly(vinyl ether)s such as thermosensitive star polymers, stimuli-responsive alternating copolymers with quantitative degradability, and thermosensitive liposomes for tumor-specific chemotherapy, is also described in the last part.

Key words: thermosensitive polymers, living polymerization, poly ( $N$-isopropylacrylamide), polymers with oxyethylene groups, thermosensitive poly(vinyl ether)s

\section{1 はじめに}

刺激応答性ポリマーとは, 温度変化などの物理的な刺 激や $\mathrm{pH}$ 変化などの化学的な刺激に応答し, その性質や 形態を変化させるポリマーのことを指す ${ }^{1)}$ 。温度変化以 外の物理的な刺激としては, 光, 磁場, 電場, 力, 電子 線, エックス線, 超音波などが, $\mathrm{pH}$ 変化以外の化学的 な刺激としては, 酸化一還元, 種々の有機·無機化合物, 酵素・抗体等の生体物質添加などがある。これらのポリ マーは比較的古くからその存在が知られており, 誘電・ 磁性材料, 圧電 · 焦電材料, 分解 · 反応性材料, 吸着 . 分離材料などの分野では, 汎用の工業材料としての利用 も多い。

一方，最近の高分子合成分野において重合法が急速に 進歩したことと，それに伴い刺激に対する応答が高感度 かつ多様になったことにより, 刺激応答性ポリマーの注 目度が急激に高くなってきた ${ }^{2)}$ 。重合法の進歩としては, リビング重合が従来のアニオン，カチオン，配位重合だ けでなく, ラジカル重合においても可能になったことが 大きく，多種類のモノマーから構造や分子量の制御され たポリマーが得られるようになった ${ }^{3)}$ 。また, 従来制御 が困難とされてきたブロック，グラフト，環状，デンド リマーなど様々な形態の刺激応答性ポリマーも合成され ている。さらに, 学術的な面では, ポリマーの設計・合 成法の開拓としての高分子合成, モルホロジーの変化や 自己組織化などの物理化学が進歩し，さまざまな分野へ の応用面では, 刺激応答性（スマート）ゲル・表面, ド ラッグデリバリー, 生体物質の分離, 酵素活性制御など の生医学分野へと広がっている ${ }^{2)}$ 。

本報では最近の動向を概観するために，刺激応答性ポ リマーの中でも特に研究の進んでいる水中で温度変化に
応答するポリマーを例にとり, リビング重合により構造 や分子量の制御されたポリマーを中心に解説する。

\section{2 温度応答性ポリマー}

\section{$2 \cdot 1$ 従来の温度応答性ポリマーおよびリビング重合 との融合}

低温の水に溶解しているポリマーがある臨界温度以上 で相分離する，いわゆる下限臨界溶液温度 (LCST) 型 相分離現象は, メチルセルロース ${ }^{4)}$ で見いだされて以 来多くの系で検討されている。これは, 水和により溶解 しているポリマーが, ある臨界温度以上になると脱水和 を起こし, 疎水性相互作用により凝集し相分離する現象 である。従来から研究されている例としては, メチルセ ルロース以外に, ポリエチレンオキシド (PEO), ポリ メチルビニルエーテル, ポリ酢酸ビニル部分けん化物, ポリ（N-イソプロピルアクリルアミド）[poly (NIPAM)] 5) などがある（Fig. 1)。しかし, いずれも当時は, 構造 や分子量の制御が困難であったり（PEO 誘導体を除き）， 刺激応答の感度が鈍いことが多く, 使用される例は限定 的であった。これらの高分子の中で, 最も詳しく検討さ れていたのが poly (NIPAM) であり ${ }^{6)}$, コイルーグロ ビュール転移によって引き起こされる LCST 型相分離 挙動を用いて，温度応答性ハイドロゲル系などに応用さ れていた。

一方, 1990 年以降に側鎖にエーテル鎖を有するビニ ルエーテルのリビングカチオン重合が, 2000 年頃には NIPAM のリビングラジカル重合が見いだされ，エーテ ル系とアミド系の二つのモノマー群から, 構造や分子量, 形態の制御された温度応答性ポリマーが合成されるよう になり，大きな進歩がみられた。特に分子量分布の狭い ポリマーやブロックポリマーの合成は, その応用を広げ 


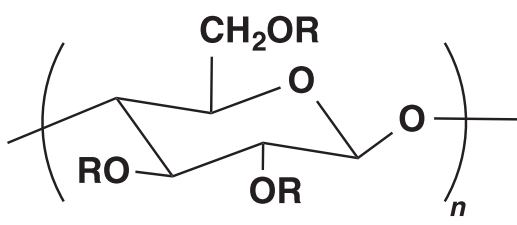

R: $\mathrm{H}$ or $\mathrm{CH}_{3}$

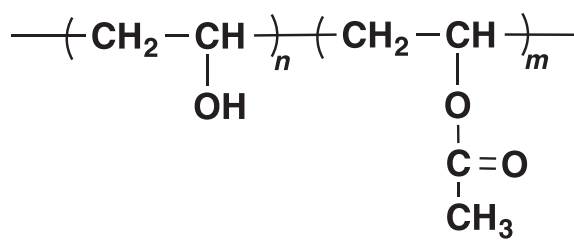

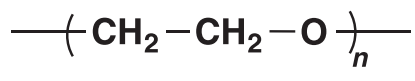
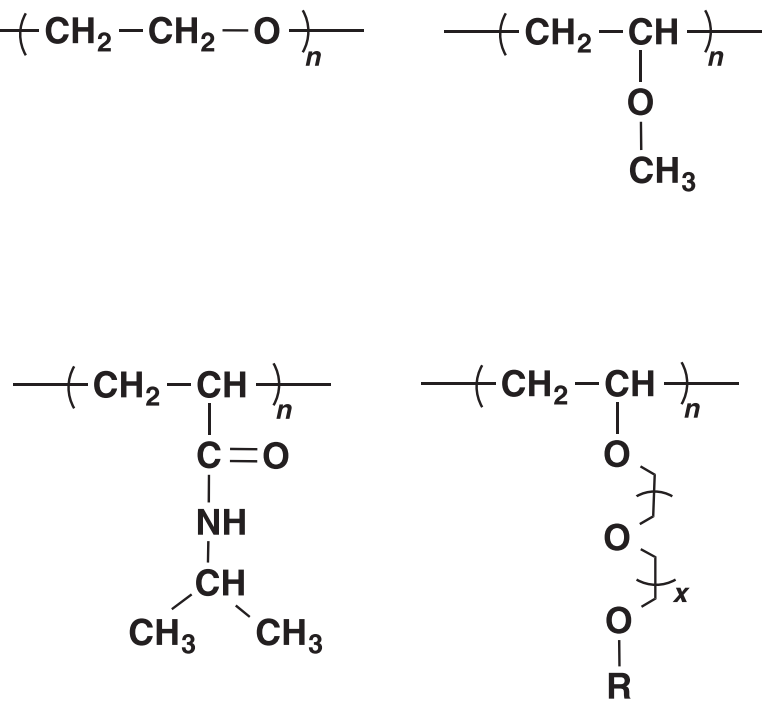

Fig. 1 従来から研究されているLCST 型温度応答性ポリマーの例およびポリ（N-イソプロピルアクリルアミド）とエーテル鎖 を有するポリビニルエーテル

る大きな役割を果たした。ここではまず, poly (NIPAM) から概略する。

poly（NIPAM）の温度応答性は 1970 年以前に見いだ されており ${ }^{5,6)}$ ，リビング重合が見いだされる以前は， AIBN（アゾビスイソブチロニトリル）や KPS（過硫酸 カリウム）などによる従来のラジカル重合により合成さ れることが多かった。末端官能性ポリマーやブロックポ リマーの合成には，岡野ら ${ }^{7)}$ やFeijen ら ${ }^{8)} に よ り$ 連鎖 移動剤などを用いた方法が用いられてきた。一方，2000 年頃から，まずRAFT 法（種々のジチオエステル類を 連鎖移動片に用いた重合法）を用いて, Rizzardo ら ${ }^{9)}$,

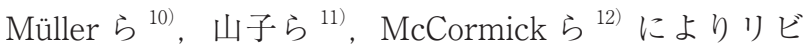
ングラジカル重合の可能性が示された。その後, TEMPO 等の安定ラジカルを用いた方法 (NMP 法) を 用いて Hawker らにより ${ }^{13)}$ ，原子移動ラジカル重合 (ATRP 法)を用いて Stöver らにより ${ }^{14)}$ ，リビング重 合が報告された。また，岡本らはリビング重合と同時に 立体構造も制御する重合を行い, 相転移温度の異なる様々 なタクチシチーの poly（NIPAM）の合成を行った ${ }^{15)}$ 。 一方，リビングアニオン重合では，北山ら ${ }^{16)}$ や石曽根 ら ${ }^{17)}$ は活性水素をシリル基などの保護基で保護したモ ノマーの重合を検討した。

poly（NIPAM）のブロックポリマーもリビングラジ カル重合を利用して非常に多く合成され，たとえば，親 水性セグメントの $\mathrm{PEO}$ ，ポリアクリル酸，ポリスルホ ン酸，ポリアクリルアミド誘導体，疎水性セグメントの ポリ乳酸，ポリスチレン，他の温度応答性ポリマーとの ブロックポリマーなどが合成されている ${ }^{2)}$ 。さらに,様々
な形態の温度応答性ポリマーとして, デンドリマー, 三 本鎖ミクトアーム型ポリマー, 星型ブロックポリマー, NIPAM ナノ微粒子が作成されている ${ }^{2)}$ 。一方，グラフ ト法により,ナノチューブ, 金コロイド, カーボンブラッ クなどの無機材料への poly（NIPAM）鎖導入も行われ た2)。

もう1つのリビング重合による LCST 型温度応答性 ポリマーとして, シンプルな分岐型 $\mathrm{PEO}$ 構造を有するビ ニルエーテルポリマー（Fig.1下右）の例をあげる ${ }^{18)}$ 。こ のモノマーは, 合成上のメリットとしてカチオン重合性 が高いビニロキシ基を有しているだけでなく，側鎖にオ キシエチレン基および様々な官能基を導入できるため, LCST 型相分離発現のための親水/疎水性のバランス調 整や機能性の付与が容易に設計できる。カチオン重合の 系統的な検討の結果, 古くは $\mathrm{HI} / \mathrm{I}_{2}$ 系で ${ }^{19)}$, 最近では添 加塩基存在下でのルイス酸によりリビング重合が可能に なり ${ }^{20)}$, 分子量分布の狭いポリマーやブロック・末端 官能性・星型ポリマー等が定量的に合成できるように なった ${ }^{220)}$ 。さらに得られたリビングポリマーは，（i ） 側鎖置換基の構造により相分離する温度が変化する, （ii）分子量・濃度依存性がある,（iii）分子量分布の狭 いポリマーが高感度な刺激応答性を示す，（iv）種々の 共重合により自由に相分離温度を設定できる，（v）官 能基導入により様々な機能を発現することなどを見いだ した。またシークエンスの効果を調べると, 分子量や分 布, 組成比が同じでもランダムポリマーでは各ホモポリ マーの中間温度で一段階の相分離がみられ，ブロックポ リマーでは二段階の相分離が起こることがわかった ${ }^{2)}$ 。 
さらに，エーテル鎖を有しない親水／疎水モノマーのラ ンダムポリマーの鋭敏な温度応答性や ${ }^{21)}$ ，ブロックポ リマーの温度に応答した様々なパターンの物理ゲル化や 自己組織化が可能になった ${ }^{2,22)}$ 。これらの結果, この系 でいち早く, 刺激応答性リビングポリマーの有用性・可 能性がアピールされた ${ }^{2)}$

\section{$2 \cdot 2$ 様々な温度応答性ポリマー}

\section{$2 \cdot 2 \cdot 1$ LCST 型温度応答性ポリマー}

ポリアミド系：Poly（NIPAM）は，相分離温度が $32^{\circ} \mathrm{C}$ 付近でその温度制御も共重合等で容易なため, 生医学分 野での応用を目指して非常に詳しく検討されている ${ }^{6)}$ 。 一方，生体親和性，ヒステリシス，末端基の依存性など に若干の懸念があり，他の構造のポリアミド類の検討も 多く行われている (Fig. 2) ${ }^{23)}$ 。アクリルアミド（メタク リルアミド）の置換基として種々のアルキル基, アミド, アルコール, ピペラジン, ピロリジンなどを有する様々 な相分離温度や特徵を有するポリマーが検討され，温度 応答カラムへの応用やブロックポリマーのゾルーゲル転 移などが検討されている。青木，緒方らは L一体および $\mathrm{DL}$ 一体のアミドポリマーを合成しそのキラル側鎖の影響 を検討したところ，DL一体に比べ ${ }_{\mathrm{L}}$ 一体のポリマーでは ヒステリシスがみられ相分離温度も低いことを見いだし た ${ }^{24)}$ 。また, アセタールやケタール基を側鎖に有する アミドポリマーは, 側鎖の加水分解の割合により相分離

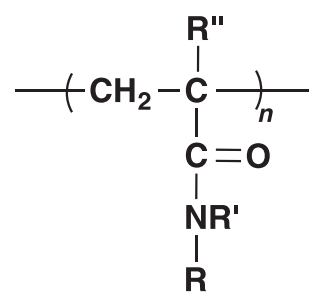

\section{R: alkyl, amide, alcohol, acetal, ketal, piperazine, pyrrolidine}

\section{$\mathbf{R}^{\prime}: \mathrm{H}, \mathrm{C}_{2} \mathrm{H}_{5}$ \\ $\mathrm{R}^{\prime \prime}: \mathrm{H}, \mathrm{CH}_{3}$}

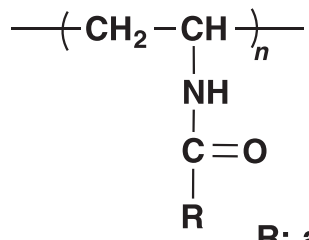

R: alkyl

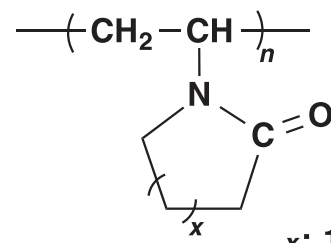

$x: 1$ or 3

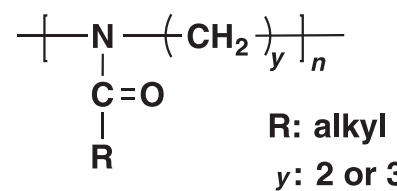

Fig. 2 ポリアミド系 LCST 型温度応答性ポリマーの例
温度を自由に変化させることが可能であった ${ }^{25)}$ 。明石 らは, 多くの $N-$ ビニルアルキルアミド系の温度応答性 ポリマー（Fig. 2 中左）を合成し ${ }^{26)}$ ，特に $\alpha$ ーヘリック スのオリゴペプチドをグラフトしたポリマーの挙動は興 味深い。主鎖にアミド結合を有する温度応答性ポリマー （Fig. 2 下）は，オキサゾリンやオキサジン誘導体のリ ビングカチオン開環重合などにより合成されている ${ }^{27)}$ 。 ポリエーテル系：直鎖状のポリエーテル系としては, 一般には分子量はそれほど大きくないが，アニオン開環 重合による PEO 型ブロックポリマー（プルロニックな ど）が合成され, 温度応答性シェル架橋型ミセルやナノ シェルが合成されている ${ }^{28)}$ 。一方，側鎖にオキシエチ レンを有するポリマーとしては，上述のポリビニルエー テルのほか, 最近では, ポリメタクリレート ${ }^{29)}$ ，ポリ スチレン ${ }^{30)}$ ， ポリノルボルネン ${ }^{31)}$ ， ポリホスファゼン ${ }^{32)}$, ポリエーテル ${ }^{33)}$, ポリラクチド ${ }^{34)}$ が様々なリビング (制 御）重合により検討されている（Fig. 3）。これらのエー テル系ポリマーの多くは低い毒性・免疫原性と高い生体 親和性のため, 生医学分野への利用が期待されている。

その他: ホスホエステル型の温度応答性ポリマー（Fig. 4 上左）は生体親和性と生分解性が特徵で, 温和な条件 で細胞毒性の無い生成物に加水分解可能なことを利用し て製薬への応用が検討されている ${ }^{35)}$ 。イオン液体型温 度応答性（LCST 型）ポリマーとしては, メタクリレー トの側鎖にスルホネートアニオンとホスホニウム対カチ オンを有するポリマー (Fig. 4 上中 ${ }^{36)}$ ， およびスチレン 側鎖にホスホニウムカチオンとアルキルスルホネート対 アニオンのポリマー ${ }^{37)}$ が合成された（Fig. 4 上右）。

タンパク質を利用した設計として, 組換え DNA 法に より両末端にロイシンジッパー, 中央にフレキシブルな 高分子電解質を有するトリブロック型人工タンパク質が 合成され，特定 $\mathrm{pH}$ や温度条件下で三次元網目を形成し た ${ }^{38)}$ 。また，RAFTなどにより合成される $\mathrm{L}$ ープロリン のポリマー（Fig. 4 下左）も温度応答性ポリマーとして 興味深い ${ }^{39)}$ 。一方，ポリペプチドの例としては，エラ スチン (Val-Pro-Gly-Val-Gly) 含有ポリマー（Fig. 4 下右） があげられる ${ }^{40)}$ 。例えば, Grubbsらは, エラスチンと $\mathrm{PEO}$ を側鎖に有するノルボルネンのポリマーを開環メ タセシス重合により合成している ${ }^{41)}$ 。また，エラスチ ン型ポリペプチドとドキソルビシンの複合体の温度応答 腫瘍抑制効果が検討された ${ }^{42)}$ 。

多分枝型の温度応答性ポリマーとしては, 星型ポリ マー, デンドリマー, ハイパーブランチポリマーが合成 されている。例えば, 河野らはポリ（アミドアミン）型 などのデンドリマーの末端に，イソブチルアミド基を導 入して温度応答性デンドリマーを合成した ${ }^{43)}$ 。星型ポ 
<smiles>CC(C)(C)C(=O)OC=[R]O</smiles><smiles>[R]C(OC)C(C)=O</smiles>

EO $_{x}$<smiles></smiles><smiles>[R]OP([R])(=O)P([Y2])(C)=O</smiles><smiles>C=CC1CC(C=C)C(C(=O)OCC)C1C(=O)O</smiles>

$\mathrm{EO}_{x} \mathrm{EO}_{x}$<smiles>CC(C)CCOC(C)C</smiles>

Fig. 3 ポリエーテル系 LCST 型温度応答性ポリマーの例（ $\mathrm{EO}_{\mathrm{x}}$ ：オキシエチレン鎖）<smiles>COCOP(=O)(OP)I(C)C</smiles><smiles>CC(C)(C)CC(C(=O)O)C(=O)N1CCCC1C(=O)O</smiles>

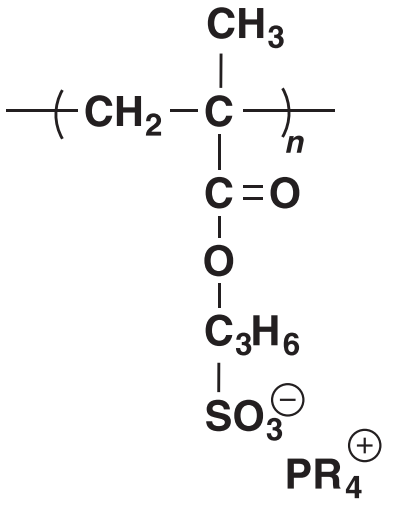

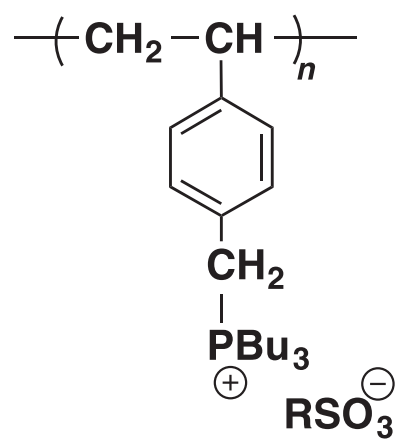

Fig. 4 各種 LCST 型温度応答性ポリマーの例

リマーの例は後述する。

\section{$2 \cdot 2 \cdot 2$ UCST 型温度応答性ポリマー}

これまで水中で昇温により高感度に相分離する LCST 型温度応答性ポリマーを述べてきたが，常圧下， $0^{\circ} \mathrm{C}$ か ら $100^{\circ} \mathrm{C}$ までの範囲で水中で降温により相分離［上限臨 界溶液温度（UCST）型する高分子は非常に少ない。 これまでの例は，側鎖間の静電相互作用によるもの（例 として, Fig. 5 左), および熱的に可逆的な水素結合を 利用するもの（例として，Fig. 5 中）の 2 つに大きく分 けられる。前者は, 側鎖にスルホベタイン基を有するポ リメタクリレートなどで ${ }^{44)}$, グループトランスファー
重合やリビングラジカル重合により制御合成が可能であ る ${ }^{45)}$ 。側鎖間の静電相互作用により降温すると相分離し, 生医学分野などへの応用が検討されている。一方後者の 水素結合を利用した例は, アクリル酸とアクリルアミド の共重合体 ${ }^{46)}$, 最近では, $\mathrm{N}-\mathrm{H}$ 基と $\mathrm{C}=\mathrm{O}$ 基とを 1 ユニッ トに有するポリマーとして, ウラシル基, ウレイド基, グ リシンアミド基含有のポリマーが検討されている ${ }^{47-49)}$ 。 また, Agarwalらは最近メタクリルアミドポリマーや アクリロニトリルとアクリルアミドのコポリマーの UCST 型相分離を報告している ${ }^{50)}$ 。多くの場合, カル ボキシ基とアミド基の水素結合によりポリマー鎖間の凝 

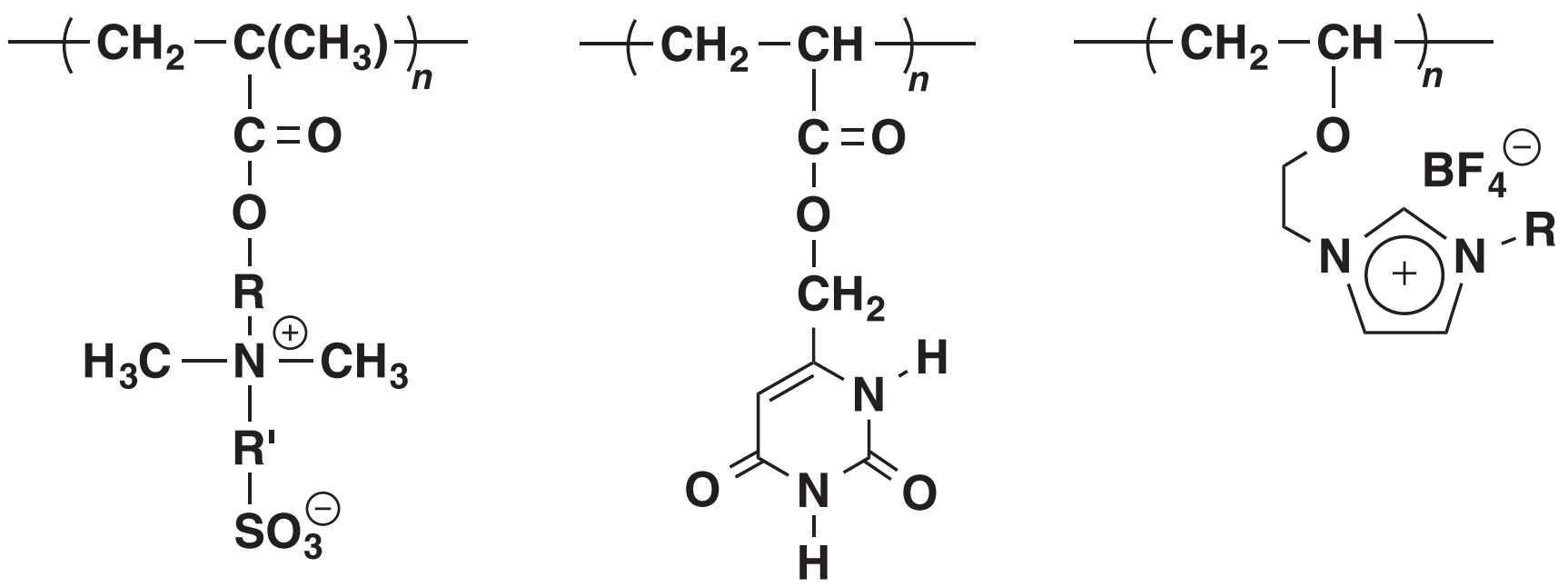

Fig. 5 UCST 型温度応答性ポリマーの例

集が起こる。このようにいくつかの例があるものの, LCST 型に比べると依然として例は少なく，リビング重 合によって合成できる系はさらに限られている。

われわれはUCST 型相分離可能なビニルエーテルポ リマーを検討し，側鎖にイミダゾリウム塩を有するポリ マーを見いだした ${ }^{51)}$ 。例えばFig. 5 右のポリマー（R= $\left.\mathrm{CH}_{3}\right)$ は，水中で $5^{\circ} \mathrm{C}$ を境にして高感度かつ可逆的に相 分離を起こす。また, 前出のLCST型ポリマーとのブロッ クポリマーは, 室温付近では溶解しているがそれ以上及 びそれ以下の温度で構造の異なる集合体を形成（コア， コロナ構造が逆転）し，高濃度ではゲルーゾルーゲル転 移（高温及び低温領域で物理ゲル化）が可能になった。

\section{3 刺激応答性ポリマーを用いた新しい展開：著者らの 研究の中から}

様々な側鎖を有する刺激応答性星型ポリマーは，直鎖 状ポリマーとは異なる物理的性質を有するため非常に興 味が持たれる。これまで, リビングポリマーにジビニル 化合物を反応させて架橋を行う方法により検討され ${ }^{52)}$, ドラッグデリバリー，遺伝子の輸送，触媒担持ミクロゲ ルへの利用が検討されている。われわれは、リビングカ チオン重合により大きさの揃った刺激応答性星型ポリ マー（Fig. 6 上）を定量的に合成することに成功した ${ }^{53)}$ 。 この星型ポリマーは単に刺激応答性を示すだけでなく, 温度応答性を利用した金ナノ微粒子担持触媒の再使用に も利用可能であった ${ }^{54)}$ 。また新しい合成法として，モ ノマー選択型の重合を用いることにより，枝ポリマーに なるモノマーとコアになるジビニル化合物を最初に添加 するだけのワンショットでの合成法も見いだした ${ }^{55)}$ 。

一方われわれは, 自然界に多数存在している共役アル デヒド化合物がビニルエーテルとカチオン交互共重合す
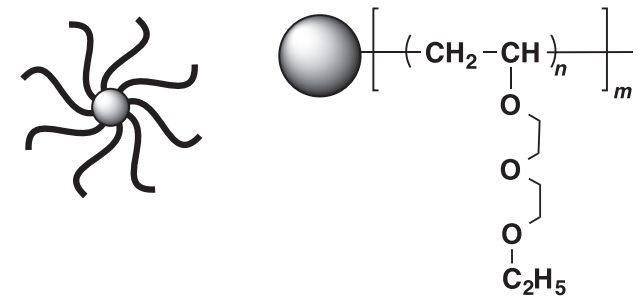

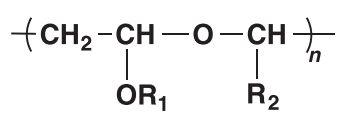

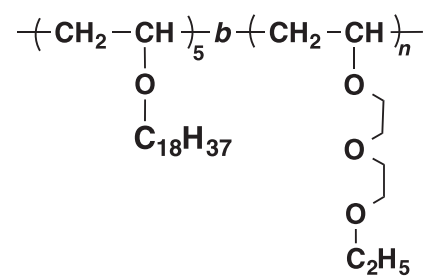

Fig. 6 星型ないし交互型温度応答性ポリマー, 温度応答性 リポソーム合成用ブロックポリマーの例

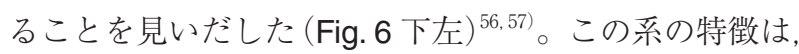
（i）ポリマー主鎖にアセタール基を交互に導入できる ので低分子にまで選択的に酸加水分解できる，（ii）重 合がリビング的に進行するので分子量分布が狭いポリ マーやブロックポリマーが合成可能，（iii）分解生成物 のアルデヒドをモノマーとして用いたリユース型重合が 可能になったことである。さらに，ビニルエーテルとし て前出のような刺激応答性を有するモノマーが使用可能 なことを利用して, 温度や $\mathrm{pH}$ 応答性を有する分解性ポ リマーが合成された ${ }^{58)}$ 。ホモポリマー同様の高感度な 刺激応答性と, 低分子化合物への選択的な分解が示され, 新しい材料系として興味が持たれる。

われわれは河野らとともに温度応答性リポソームを合 成し, 体内の標的組織に薬物や生理活性物質を到達させ, 選択的に放出させる精度の高いドラッグデリバリー法の 
開発を行った ${ }^{59)}$ 。具体的には，長鎖アルキル基を末端 アンカーとした温度応答性ブロックコポリマー（Fig. 6 右下）を合成し，これを抗癌剤を含んだリポソームに複 合化した。このリポソームを担癌マウスに投与し，3〜 12 時間後に腫瘍病巣に体外から $45^{\circ} \mathrm{C}$ で 10 分間加温した ところ, 抗癌剤を効率よく放出し, 腫瘍成長が強く抑制 された ${ }^{60)}$ 。一方, リポソームへの疎水化酸化鉄の導入 により交流磁場印加による薬物の選択的放出の検討も行 なった ${ }^{61)}$ 。

\section{4 最後に}

自然界に存在する「優れた性能や特異的な機能を有す る材料」には, 刺激応答性ポリマーが関与していること が多い。しかもそれらは，一次構造や分子量が揃ってい るだけでなく，機能に合わせて高次構造や集合状態まで 完全に制御されている。その意味では，刺激応答性ポリ マーがリビング重合と出会い, 構造が制御された新材料 が設計・合成されてきたことは自然な流れである。しか し，現状ではその制御はまだまだ緒に就いたばかりであ り，今後は，それらの会合・集合状態の制御までを見据 えた高次構造の設計・合成法の開拓が重要課題である。 高次構造制御への例として, 覚知らは, クラウンエーテ ル側鎖のポリ（フェニルアセチレン）を用い, 温度応答 ホストーゲスト化学を利用したらせんの on/offを制御す る方法を明らかにした ${ }^{62)}$ 。また, 新海らは, ポリチオフェ ンと PEO 修飾したカードランが形成する錯体が，温度 刺激によってらせんの巻きおよび色が変化することを見 いだした ${ }^{63)}$ 。このような方向の研究が, 今後次々と進 められるであろう。

もう 1 つの課題は，無機材料との複合体形成である。 天然に多く存在する理想的な有機／無機の融合材料を得 るために，刺激応答性ポリマーを用いた，無機材料との 界面でのセグメント配列やモルホロジー制御等の精密な 分子設計が必要になる。それらは, 傾斜構造, 自己分解・ 修復機能，動的な界面などの形成に繋がっていく。その ために今後は, 高分子の合成化学や物理化学だけでなく, 無機化学や生化学などの他分野と強く連携していくこと が不可欠であろう。

\section{参考文献}

1) A. S. Hoffman, Macromol. Symp., 98, 645 (1995).

2) 総説として, S. Aoshima, S. Kanaoka, Adv. Polym. Sci., 210, 169 (2008)

3）総説として, “Controlled/Living Radical Polymerization”, K. Matyjaszewski Ed., ACS Symp. Series, 768 (2000).

4) E. Heymann, Trans. Faraday Soc., 31, 846 (1935).
5) H. G. Schild, Prog. Polym. Sci., 17, 163 (1992).

6) B. Jeong, A. Gutowska, Trends in Biotechnol., 20, 305 (2002).

7) S. Cammas, K. Suzuki, C. Sone, Y. Sakurai, K. Kataoka, T. Okano, J. Controlled Release, 48, 157 (1997).

8) M. D. C. Topp, P. J. Dijkstra, H. Talsma, J. Feijen, Macromolecules, 30, 8518 (1997).

9) F. Ganachaud, M. J. Monteiro, R. G. Gilbert, M. Dourges, S. H. Thang, E. Rizzardo, Macromolecules, 33, 6738 (2000).

10) C. Schilli, M. G. Lanzendörfer, A. H. E. Müller, Macromolecules, 35, 6819 (2002).

11) A. Goto, Y. Kwak, T. Fukuda, S. Yamago, K. Iida, M. Nakajima, J. Yoshida, J. Am. Chem. Soc., 125, 8720 (2003).

12) A. J. Convertine, N. Ayres, C. W. Scales, A. B. Lowe, C. L. McCormick, Biomacromolecules, 5, 1177 (2004).

13) A. W. Bosman, R. Vestberg, A. Heumann, J. M. J. Fréchet, C. J. Hawker, J. Am. Chem. Soc., 125, 715 (2003).

14) Y. Xia, X. Yin, N. A. D. Burke, H. D. H. Stöver, Macromolecules, 38, 5937 (2005).

15) B. Ray, Y. Isobe, K. Morioka, S. Habaue, Y. Okamoto, M. Kamigaito, M. Sawamoto, Macromolecules, 36, 543 (2003).

16) T. Kitayama, W. Shibuya, K. Katsukawa, Polym. J., 34, 405 (2002).

17) T. Ishizone, M. Ito, J. Polym. Sci., Part A: Polym. Chem., 40, 4328 (2002).

18) S. Aoshima, H. Oda, E. Kobayashi, J. Polym. Sci., Part A: Polym. Chem., 30, 2407 (1992).

19) T. Nakamura, S. Aoshima, T. Higashimura, Polym. Bull., 14, 515 (1985).

20）総説として, S. Aoshima, S. Kanaoka, Chem. Rev., 109, 5245 (2009)

21) S. Sugihara, S. Kanaoka, S. Aoshima, Macromolecules, 37, 1711 (2004).

22) S. Sugihara, K. Hashimoto, S. Okabe, M. Shibayama, S. Kanaoka, S. Aoshima, Macromolecules, 37, 336 (2004).

23）総説として, D. Roy, W. L. A. Brooks, B. S. Sumerlin, Chem. Soc. Rev., 42, 7214 (2013).

24) T. Aoki, M. Muramatsu, T. Torii, K. Sanui, N. Ogata, Macromolecules, 34, 3118 (2001).

25) Y. Zou, D. E. Brooks, J. N. Kizhakkedathu, Macromolecules, 41, 5393 (2008).

26) K. Suwa, Y. Wada, Y. Kikunaga, K. Morishita, A. Kishida, M. Akashi, J. Polym. Sci., Part A: Polym. Chem., 35, 1763 (1997).

27) H. Uyama, S. Kobayashi, Chem. Lett., 1643 (1992).

28）総説として, K. te Nijenhuis, Adv. Polym. Sci, 130, 1 (1997).

29) S. Han, M. Hagiwara, T. Ishizone, Macromolecules, 36, 8312 (2003)

30) B. Zhao, D. Li, F. Hua, D. R. Green, Macromolecules, 38, 9509 (2005).

31) T. Bauer, C. Slugovc, J. Polym. Sci., Part A: Polym. 
Chem., 48, 2098 (2010).

32) H. R. Allcock, S. R. Pucher, M. L. Turner, R. J. Fitzpatrick, Macromolecules, 25, 5573 (1992).

33) S. Inoue, H. Kakikawa, N. Nakadan, S. Imabayashi, M. Watanabe, Langmuir, 25, 2837 (2009).

34) X. Jiang, M. R. Smith, III, G. L. Baker, Macromolecules, 41, 318 (2008).

35) Y. Iwasaki, C. Wachiralarpphaithoon, K. Akiyoshi, Macromolecules, 40, 8136 (2007).

36) Y. Kohno, Y. Deguchi, H. Ohno, Chem. Commun., 48, 11883 (2012)

37) Y. Men, H. Schlaad, J. Yuan, ACS Macro Lett., 2, 456 (2013).

38) W. A. Petka, J. L. Harden, K. P. McGrath, D. Wirtz, D. A. Tirrell, Science, 281, 389 (1998).

39) H. Mori, I. Kato, T. Endo, Macromolecules, 42, 4985 (2009).

40) D. E. Meyer, B. C. Shin, G. A. Kong, M. W. Dewhirst, A. Chilkoti, J. Controlled Release, 74, 213 (2001).

41) R. M. Conrad, R. H. Grubbs, Angew. Chem., Int. Ed., 48, 8328 (2009).

42) M. R. Dreher, D. Raucher, N. Balu, O. Michael Colvin, S. M. Ludeman, A. Chilkoti, J. Controlled Release, 91, 31 (2003).

43) Y. Haba, A. Harada, T. Takagishi, K. Kono, J. Am. Chem. Soc., 126, 12760 (2004).

44) D. N. Schulz, D. G. Peiffer, P. K. Agarwal, J. Larabee, J. J. Kaladas, L. Soni, B. Handwerker, R. T. Garner, Polymer, 27, 1734 (1986).

45) M. Arotçaréna, B. Heise, S. Ishaya, A. Laschewsky, J. Am. Chem. Soc., 124, 3787 (2002).

46) T. Aoki, K. Nakamura, K. Sanui, A. Kikuchi, T. Okano, Y. Sakurai, N. Ogata, Polym. J., 31, 1185 (1999).

47）大西徳幸, 古川裕考, 近藤昭彦, 応用物理, 72, 909 (2003).

48) J. Seuring, F. M. Bayer, K. Huber, S. Agarwal, Macro- molecules, 45, 374 (2011).

49) N. Shimada, H. Ino, K. Maie, M. Nakayama, A. Kano, A. Maruyama, Biomacromolecules, 12, 3418 (2011).

50) J. Seuring, S. Agarwal, Macromolecules, 45, 3910 (2012).

51) H. Yoshimitsu, A. Kanazawa, S. Kanaoka, S. Aoshima, Macromolecules, 45, 9427 (2012).

52) S. Kanaoka, M. Sawamoto, T. Higashimura, Macromolecules, 24, 2309 (1991).

53) T. Shibata, S. Kanaoka, S. Aoshima, J. Am. Chem. Soc., 128, 7497 (2006).

54) S. Kanaoka, N. Yagi, Y. Fukuyama, S. Aoshima, H. Tsunoyama, T. Tsukuda, H. Sakurai, J. Am. Chem. Soc., 129, 12060 (2007).

55) S. Kanaoka, M. Yamada, J. Ashida, A. Kanazawa, S. Aoshima, J. Polym. Sci., Part A: Polym. Chem., 50, 4594 (2012).

56) Y. Ishido, R. Aburaki, S. Kanaoka, S. Aoshima, Macromolecules, 43, 3141 (2010).

57) Y. Ishido, A. Kanazawa, S. Kanaoka, S. Aoshima, Macromolecules, 45, 4060 (2012).

58) S. Aoshima, Y. Oda, S. Matsumoto, Y. Shinke, A. Kanazawa, S. Kanaoka, ACS Macro Lett. in press.

59) K. Kono, T. Murakami, T. Yoshida, Y. Haba, S. Kanaoka, T. Takagishi, S. Aoshima, Bioconjugate Chem., 16, 1367 (2005)

60) K. Kono, T. Ozawa, T. Yoshida, F. Ozaki, Y. Ishizaka, K. Maruyama, C. Kojima, A. Harada, S. Aoshima, Biomaterials, 31, 7096 (2010).

61) K. Katagiri, Y. Imai, K. Koumoto, T. Kaiden, K. Kono, S. Aoshima, Small, 7, 1683 (2011).

62) R. Sakai, I. Otsuka, T. Satoh, R. Kakuchi, H. Kaga, T. Kakuchi, Macromolecules, 39, 4032 (2006).

63) T. Shiraki, A. Dawn, Y. Tsuchiya, S. Shinkai, J. Am. Chem. Soc., 132, 13928 (2010). 